\title{
KEGIATAN PENYULUH PERTANIAN LAPANGAN (PPL) KECAMATAN TANAH SEPENGGAL LINTAS KABUPATEN BUNGO
}

\author{
FIELD FARMING ACTIVITIES (PPL) \\ KECAMATAN TANAH SEPENGGAL LINTAS DISTRICT BUNGO
}

\section{Isyaturriyadhah, Sopia Anismar}

Program Studi Agribisnis, Fakultas Pertanian, Universitas Muara Bungo

Jambi 37228, Indonesia

e-mail: isyaturriyadhah_amin@yahoo.com, soviaanimar@yahoo.com

\begin{abstract}
ABSTRAK
Kehadiran tenaga penyuluh pertanian lapangan (PPL) sangatlah penting artinya bagi petani karena petugas penyuluh pertanian lapangan merupakan ujung tombak dari keberhasilan kegiatan pembangunan pertanian. Dalam menjalankan tugasnya PPL dibatasi oleh suatu Wilayah Kerja Penyuluhan Pertanian (WKPP) yang terdapat di dalam Wilayah Kerja Balai Penyuluh Pertanian. Tujuan dari penelitian ini adalah untuk mengetahui kesesuaian kegiatan PPL di Kecamatan Tanah Sepenggal Lintas Kabupaten Bungo. Dalam penelitian ini di gunakan pendekatan diskriptif kuantitatif. Responden dalam penelitian ini adalah 2 orang penyuluh dan 41 orang anggota kelompok tani. Untuk mengetahui kegiatan penyuluhan dan kesesuaian kegiatan penyuluh dihitung dengan menggunakan skala likert. Hasil Penelitian menunjukkan bahwa skor kesesuaian pelaksanaan tugas PPL secara keseluruhan adalah 2570 dan dikatakan berada pada kategori sesuai dengan rencana kegiatan yang telah dibuat sebelumnya.
\end{abstract}

Keywords : Kegiatan; PPL; Kesesuaian

\section{ABSTRACT}

The presence of agricultural extension workers is very important for farmers because field extension workers are the spearhead of agricultural development activities. In carrying out its duties, PPL is limited by an Agricultural Extension Work Area (WKPP) contained within the Agricultural Extension Workers Work Area. The purpose of this study was to determine the suitability of the Field Agricultural Extension (PPL) activities in the Tanah Sepenggal Subdistrict, Bungo District. In this research a quantitative descriptive approach is used. Respondents in this study were 2 instructors and 41 members of farmer groups. To find out the extension activities and the appropriateness of extension activities, Likert scale is used. The results showed that the overall suitability score of the PPL task implementation was 2570 and said to be in the appropriate category.

Keywords: Activity; PPL; Conformity 


\section{Pendahuluan}

Kehadiran tenaga penyuluh pertanian lapangan (PPL) sangatlah penting artinya bagi petani karena petugas penyuluh pertanian lapangan adalah ujung tombak dari kegiatan pembangunan pertanian (Samsuddin, 1987). Dalam menjalankan tugasnya PPL dibatasi oleh suatu Wilayah Kerja Penyuluhan Pertanian (WKPP) yang terdapat di dalam Wilayah Kerja Balai Penyuluh Pertanian. Penyuluh Pertanian Lapangan (PPL) tersebut bertugas menangani masalah-masalah pertanian sesuai dengan pendidikan dan keahlian yang dimilikinya.

Seorang PPL dapat membantu petani dalam usaha mereka meningkatkan produksi dan mutu hasil produksinya guna meningkatkan kesejahteraan petani. Oleh karena itu penyuluh mempunyai banyak peran antara lain sebagai pembimbing petani, organisator, dinamisator, pelatih, teknisi dan jembatan penghubung antara keluarga petani dan instansi penelitian dibidang pertanian (Mardikanto, 1993)(Mardikanto, 2003). Disamping itu penyuluh pertanian selalu mengacu kepada kegiatan-kegiatan yang ada dan dapat di temui dilapangan atau harus selalu disesuaikan dengan keadaan yang dihadapi, yang ditujukan kepada para petani dan keluarganya yang berlangsung terus-menerus agar mereka mau dan mampu meningkatkan jumlah dan mutu produksi usaha mereka dan diharapkan dapat menaikan taraf hidupnya dengan menjaga kelestarian lingkungannya. Karena sifatnya yang demikian, maka penyuluhan bisa juga disebut pendidikan nonformal (Kartono, 2008).

Seseorang PPL yang mampu mewujudkan tujuan penyuluhan pertanian dikatakan telah melakukan penyuluhan yang mempunyai dampak atau berhasil guna sesuai dengan program yang telah direncanakan sebelumnya. Menurut Mardikanto (1993), rencana kerja merupakan rencana kegiatan yang akan dilaksanakan demi tercapainya tujuan yang diharapkan. Dengan adanya rencana kerja pelaksanaan penyuluhan dapat dilakukan secara terorganisir (Adenan, 2004), sehingga evaluasi terhadap penyuluhan lebih akurat dan mudah untuk dilaksanakan.

Penyuluh Pertanian Lapangan di Kecamatan Tanah Sepenggal Lintas bertugas untuk mewujudkan kesejahteraan petani dengan menggunakan teknologi-teknologi yang terbaru berdasarkan rencana kerja yang telah disusun. Penyuluh Pertanian Lapangan tersebut adalah penyuluh yang membina kelompok tani sesuai dengan wilayah binaannya. Fungsi dari penyuluh tersebut adalah membuat kegiatan-kegiatan yang berkaitan dengan minat kebutuhan petani dan memudahkah petani untuk mencapai tujuan. Kegiatan penyuluhan yang dilaksanakan pada kelompok tani 
di Kecamatan Tanah Sepenggal Lintas banyak terdapat di 2 Desa yaitu desa Paku Aji dan desa Sungai Puri yang merupakan desa yang memiliki kelompok tani terbanyak yaitu sebanyak 10 kelompok tani, jika dibandingkan dengan desa-desa lain yang ada di Kecamatan Tanah Sepenggal Lintas.

Sehingga tujuan penelitian ini adalah untuk mengetahui kesesuaian kegiatan yang dilakukan oleh PPL dalam melaksanakan tugasnya di lapangan.

\section{Metode Penelitian}

Penelitian dilaksanakan di Desa Paku Aji dan Sungai Puri Kecamatan Tanah Sepenggal Lintas Kabupaten Bungo. Metode penelitian ini menggunakan metode survey. Survey yaitu dengan cara pengamatan langsung ke lokasi penelitian dan menggunakan kuesioner sebagai alat pengumpulan data yang pokok (Sugiyono, 2011) (Yitnosumarto. 2006). Dalam penelitian ini di gunakan pendekatan diskriptif kuantitatif. Responden dalam penelitian ini adalah 2 orang penyuluh dan 41 orang anggota kelompok tani. Untuk mengetahui kegiatan penyuluhan dan kesesuaian kegiatan penyuluh digunakan perhitungan dengan skala likert.
Kegiatan PPL dalam penelitian yaitu :

1) Membuat dan melaksanakan rencana kerja

2) Membina kelompok tani.

3) Menyampaikan informasi, memberikan pengetahuan dan teknologi pertanian.

4) Membantu terselenggaranya usahausaha kegiatan petani dengan pemecahan masalah.

Kegiatan di atas dianalisis kemudian dinilai kesesuaiannya dengan kriteria : Sesuai (1926-2625), Kurang sesuai (skor 1225-1925) dan Tidak sesuai (skor 525-1224)

\section{Hasil Dan Pembahasan}

\section{Identitas Responden}

1. Umur

persentase umur terbesar pada petani di daerah penelitian adalah 26 - 40 tahun yaitu sebesar 39,03 $\%$ (15 orang) sedangkan untuk persentase umur penyuluh adalah $100 \%$ (2 orang) berada pada kisaran antara 36-42 tahun.

Angka tersebut menunjukkan bahwa mayoritas petani dan penyuluh berusia produktif, yang aktif dalam menyebarkan inovasi baru dan informasi-informasi yang dibutuhkan oleh petani, karena pada usia tersebut petani dan penyuluh mempunyai kemampuan fisik yang kuat dan dinamis, serta masih memiliki kemauan untuk mengembangkan diri. 
2. Pendidikan

Sebagian besar petani responden berpendidikan, SD yaitu sebanyak 4 petani $(9,75 \%)$, sedangkan yang berpendidikan SMP sebanyak 15 petani $(36,58$ $\%$ ), yang berpendidikan SMA sebanyak 18 petani $(43,91 \%)$ dan berpendidikan D3 dan S1 sebanyak 4 petani $(9,75 \%)$.

Faktor pendidikan dapat mempengaruhi petani dalam mengadopsi teknologi baru dimana tingkat pendidikan pada umumnya akan mempengaruhi cara berpikir petani. Petani yang memperoleh pendidikan lebih tinggi besar kemungkinannya mempunyai sikap lebih cepat menerima dan menyerap teknologi baru dari pada tingkat pendidikan rendah yang cenderung menutup diri terhadap penemuan-penemuan baru yang berkaitan dengan pengembangan usahataninya.

Hasil penelitian juga diketahui bahwa untuk pendidikan PPL dalam penelitian ini yaitu Sarjana (S1). Pendidikan merupakan syarat penting dalam usaha menyebarkan informasi-informasi baru kepada petani, karena dengan pendidikan dan kemampuan yang dimiliki penyuluh tersebut maka informasi-informasi yang disampaikan kepada petani akan mudah diterima dan dalam penyampaian informasi tersebut sangat dipengaruhi oleh tingkat pendidikan dan wawasan

penyuluh.

3. Pengalaman Kerja Petani dan Penyuluh.

Pengalaman bekerja petani responden terbesar di daerah penelitian adalah berkisar 6-10 tahun berjumlah 12 orang $(36,58 \%)$.

Semakin banyak pengalaman yang dimilki oleh petani maka akan bijak dalam mengambil keputusan. Pengalaman bertani akan diperoleh seseorang berdasarkan lama mereka bergerak dalam suatu kegiatan di bidang pertanian.

Hasil penelitian menunjukkan bahwa pengalam kerja penyuluh 5-10 tahun. Pengalaman bekerja merupakan salah satu faktor yang berperan penting dalam pengambilan keputusan. Pengalaman penyuluh menunjukkan keuletan dan kematangan dalam menghadapi berbagai masalah yang dialami oleh penyuluh. Pengalaman bekerja penyuluh diukur dalam tahun sejak penyuluh pertama kali bekerja.

\section{Kegiatan PPL}

\section{Membuat dan Melaksanakan Rencana Kerja}

Rencana kerja merupakan rencana kegiatan yang akan dilaksanakan demi tercapainya tujuan yang diharapkan. Dengan adanya rencana kerja ini pelaksanaan penyuluhan dapat dilakukan secara terorganisir, sehingga evaluasi 
terhadap penyuluhan lebih akurat dan mudah untuk dilaksanakan.

$$
\text { Penelitian ini mengukur }
$$
rencana kerja yang dibuat dan dilaksanakan meliputi kegiatan PPL dalam membuat dan menyusun rencana kerja, mengesahkan rencana kerja, menyusun rencana jadwal kunjungan, memberitahukan jadwal kunjungan, frekuensi pertemuan kelompok dan prosedur kunjungan.

Pelaksanaan tugas PPL membuat dan melaksanakan pogram kerja dalam kategori sesuai hal ini terlihat dari nilai total skor pertanyaan yaitu 805. Realisasi kegiatan bila diurutkan, yang paling sesuai yang dilakukan oleh penyuluh adalah kegiatan menyusun kerja, kegiatan pengesahan rencana kerja, kegiatan pertemuan kelompok tani, memberi tahu jadwal kunjungan, mengadakan pertemuan disetiap wilayah kerja, kunjungan PPL terhadap aktivitas lain dan yang terakhir adalah kegiatan penyusunan jadwal kunjungan.

\section{Membina Kelompok Tani}

Pembinaan kelompok tani adalah usaha memberikan kesempatan belajar kepada para anggota kelompok tani untuk mendapatkan kesamaan pikiran dan tujuan, sehingga mereka mampu bekerjasama dalam menanggulangi setiap masalah yang timbul dalam penyelenggaraan usahatani di kawasannya.

Tugas PPL di lokasi penelitian adalah membina kelompok tani, untuk meningkatkan efektifitas sistem kerja latihan dan kunjungan dari kegiatan penyuluhan dan guna menumbuhkan serta mengembangkan peran serta petani dalam pembangunan pertanian. Hal ini sesuai dengan pendapat Suhardiyono (1992) yang menyatakan bahwa untuk mengembangkan partisipasi petani maka dipandang perlu untuk melakukan pembinaan terhadap kelompok-kelompok tani yang telah terbentuk.

Kategori kesesuaian dimensi pelaksanaan tugas PPL membina kelompok tani berdasarkan perhitungan skoring berada pada kategori sesuai. Petani merasa antusias untuk ikut serta dalam pembinaan dan pelatihan yang diberikan karena ingin menambah wawasan yang dimiliki, selain itu waktu pelaksanaan kegiatan dan pelatihan yang fleksibel sehingga mempermudah petani untuk menghadiri kegiatan disamping itu juga pembinaan dan pelatihan yang diberikan sesuai dengan kebutuhan dan minat petani.

Berdasarkan keterangan yang diperoleh dari pihak PPL bahwa kegiatan pelatihan dan pembinaan kelompok tani tetap diadakan dan materi yang diberikan disesuaikan dengan keinginan dari kelompok tani berdasarkan kebutuhan kelompok. Selain itu pelaksanaan tugas PPL membina kelompok tani diindikasi oleh upaya keras PPL di lapangan untuk selalu berusaha mencari solusi masalah pertanian yang diajukan petani binaan secara tepat dan cepat, pada saat pertemuan di kelompok atau saat kunjungan ke wilayah kerja. 
Kesempatan menyampaikan saran yang terkait dengan pembinaan kelompok tani dan masalah pertanian pada pertemuan rutin di BPP atau di Dinas merupakan alasan lain pendorong semangat PPL dalam bekerja. Penyelenggaraan penyuluhan pertanian yang terstruktur, secara tidak langsung juga menjadi sarana pemantau kinerja, kunjungan (karyawisata) ke daerah lain untuk melihat keberhasilan pelaksanaan kegiatan penyuluhan di daerah lain, sebagai bahan pembanding.

\section{Menyampaikan informasi, memberikan pengetahuan dan teknologi pertanian.}

Beberapa hal yang diamati dalam pelaksanaan tugas PPL adalah membantu terselenggaranya kegiatan petani yang bersangkutan dengan pemecahan masalah dalam arti kegiatan yang dilakukan PPL yaitu membantu petani memecahkan berbagai permasalahan yang dihadapinya. Pelaksanaan tugas menyampaikan informasi pertanian, mengajarkan pengetahuan dan teknologi pertanian dalam kategori sesuai dengan nilai skor 1970. Penyuluh memiliki pertimbangan tertentu untuk kegiatan pertanian yang diberikan pada responden dengan menyesuaikannya dengan nilai loyalitas kelompok tani dan kemampuan responden untuk mengembangkan usaha pertaniannya tersebut, memperoleh pengetahuan agar tidak menyulitkan responden itu sendiri dan informasi yang diperoleh bermanfaat sehingga bisa membantu mereka dimasa yang akan datang.

\section{Membantu terselenggaranya usaha-usaha kegiatan petani dengan pemecahan masalah.}

Beberapa hal yang dilihat dalam pelaksanaan tugas PPL adalah membantu terselenggaranya kegiatan petani yang menjadi binaannya dengan pemecahan masalah, artinya kegiatan PPL membantu petani memecahkan berbagai permasalahan yang dihadapi.

Skor yang diperoleh dalam indikator ini sebesar 2500 dan dikatakan sesuai. Artinya responden benar-benar merasakan bantuan pemecahan masalah yang dilakukan melalui kegiatan penyuluhan untuk keperluan usaha kelompok tani. Berdasarkan informasi dari responden, mereka memang memiliki tujuan untuk meningkatkan produksi dari kegiatan usahatani yang dijalankannya, karena itu responden memanfaatkan bantuan yang di berikan oleh pemerintah dan juga setiap pelatihanpelatihan yang diadakan untuk peningkatan produksi usahataninya. Sehingga diharapkan terjadi perubahan yang dimaksudkan adalah perubahanperubahan yang lebih baik. Hal ini sesuai dengan pendapatan Kartasapoetra (1994) bahwa terjadi perubahan-perubahan yang tadinya bersifat kurang menguntungkan 
menjadi sesuatu yang lebih baik dan lebih menguntungkan.

Berdasarkan hasil penelitian diperoleh skor rata-rata kesesuaian pelaksanaan tugas PPL secara keseluruhan adalah 2570 dan dikatakan sesuai karena berada dalam interval 1926-2625 berdasarkan kriteria yang telah ditentukan.

Dari hasil penelitian diketahui bahwa petani benar-benar merasakan bantuan pemecahan masalah yang dilaksanakan melalui kegiatan penyuluhan untuk keperluan usahatani kelompok tani. Berdasarkan informasi dari responden, mereka memang memiliki tujuan untuk meningkatkan produksi usahatani yang dijalankan, karena itu responden memanfaatkan bantuan yang di berikan oleh pemerintah untuk peningkatan produksi. Misalnya, kegiatan SLPTT, SRI, Optimasi lahan mengatasi masalah hama dan penyakit tanaman.

\section{Kesimpulan Dan Saran}

\section{Kesimpulan}

\section{Kesesuaian}

Berdasarkan Skor kegiatan

Pelaksanaan Tugas PPL dalam membuat dan melaksanakan rencana kerja, membina kelompok tani, menyampaikan informasi, memberikan pengetahuan dan teknologi pertanian, serta membantu terselenggaranya usaha-usaha kegiatan petani dengan pemecahan masalah dengan pencapaian skor 2570 berada pada kategori sesuai dengan rencana kegiatan yang telah dibuat sebelumnya.

\section{Saran}

Perlu ditingkatkan sarana dan prasarana seperti alat peraga, gambar contoh dan lain-lain yang menunjang dalam penyampaian informasi kepada petani dan PPL harus lebih sering mengikuti seminar atau pelatihan untuk meningkatkan wawasan sehingga informasi yang akan di berikan selalu update dan bisa diterima dengan lebih baik oleh petani.

\section{Daftar Pustaka}

Adenan, 2004. Efektifitas Penyuluhan; Petunjuk bagi Penyuluh Pertanian. Erlangga. Jakarta.

Kartono. 2008. Pengertian Penyuluhan Pertanian dan Sistem Pengukuran Kinerja Berbasis Kompetensi. Raja Grafindo Persada. Surakarta

Kartasapoetra. 1994. Teknologi Penyuluhan Pertanian. Bina Aksara. Jakarta

Mardikanto 1993.Sistem Kerja Penyuluhan Pertanian dan Pembangunan Pertanian Surakarta.Sebelas Maret University Press. Surakarta

Mardikanto. 1993. Penyuluhan Pembangunan Pertanian. Sebelas Maret University Press. Surakarta.

Mardikanto, 2003. Redefinisi dan Revitalisasi Penyuluhan Pembangunan, dalam 
Membentuk Pola Perilaku Manusia Pembangunan. IPB Press, Bogor.

Suhardiyono., 1992. Penyuluhan, Petunjuk bagi penyuluh pertanian, Erlangga, Jakarta.

Samsudin. 1987. Dasar-dasar Penyuluhan Pertanian dan
Modernisasi Pertanian. Bina Cipta. Jakarta.

Sugiyono (2011). Metode penelitian kuntitatif kualitatif dan R\&D. Alfabeta

Yitnosumarto. 2006. Metode

Penelitian Kuantitatif dan Kualitatif. Buku. Graha Ilmu Yogyakarta 